\title{
Corrosion Behaviour of Carbon Steel in Biodiesel-Diesel-Ethanol (BDE) Fuel Blend
}

\author{
Saravana Kannan Thangavelu, ${ }^{1,2, a}$, Piraiarasi Chelladorai ${ }^{1, \mathrm{~b}}$ and Farid Nasir $\mathrm{Ani}^{2, \mathrm{c}}$ \\ ${ }^{1}$ Faculty of Engineering, Computing and Science, Swinburne University of Technology, Kuching, Sarawak, Malaysia \\ ${ }^{2}$ Faculty of Mechanical Engineering, Universiti Teknologi Malaysia, Skudai, Johor D.T., Malaysia
}

\begin{abstract}
The biodiesel-diesel-ethanol blend represents an important alternative fuel for diesel engines; however, changes in the fuel composition and the introduction of new alternative fuel often results in corrosion and degradation of the automobile fuel system parts. In this present study, the corrosion behavior of carbon steel in B20D70E10 (biodiesel $20 \%$, diesel $70 \%$ and ethanol $10 \%$ ) fuel blend was studied by static immersion at room temperature and $60{ }^{\circ} \mathrm{C}$. The effect of B20D70E10 fuel blend on corrosion rate, morphology of corrosion products, and chemical structure of carbon steel were studied. In addition, the change of fuel properties, namely, total acid number, density, viscosity, calorific value, flash point, and color changes were also investigated. Moreover, fuel compositional changes, such as water content and oxidation product level in the fuel blends were examined. The results showed that the degradation of fuel properties and corrosion rate of carbon steel in B20D70E10 are lower than neat biodiesel (B100), whereas slightly higher than petro-diesel (B0)
\end{abstract}

\section{Introduction}

The increasing demands of petroleum-based fuels together with the environmental pollution issues have motivated the efforts on discovering new alternative fuels. Biofuels, especially ethanol/bioethanol and biodiesel have gained progressive importance as alternative fuels for internal combustion engines [1]. The blends of diesel and ethanol could be used in existing diesel engines without engine modification, but the major drawback in diesel-ethanol (DE) fuel blends is, that ethanol is immiscible in diesel. However, biodiesel is miscible in both diesel and ethanol; moreover, can act as an emulsifier for DE blend to form biodiesel-diesel-ethanol (BDE) blend, which can be used in diesel engines [2]. A maximum of $30 \%$ biodiesel (ethyl or methyl ester) and ethanol blend can be added to diesel fuel effectively. In addition, most of the researchers recommend that a maximum of $20 \%$ (Vol.) biodiesel and 10\% (Vol.) ethanol can be used in diesel engine for better engine performance and emissions [3]. The BDE blend represents an important alternative fuel for diesel engines; however, changes in the fuel composition and the introduction of new alternative fuel often results in corrosion and degradation of the automobile fuel system parts. The diesel engine parts made from carbon steel, such as fuel tank, fuel lines, and fuel tube outlet are normally affected by the fuel blends. Many researchers have investigated the corrosion behavior of carbon steel in different biodiesel. Literatures show a gap that there is no study reported on corrosion behavior of carbon steel in
BDE fuel blend, and the corrosive nature of BDE fuel on carbon steel. The objective of this study is to investigate effect of these BDE blends on corrosion behavior of carbon steel. In addition, the impact of carbon steel on degradation of BDE fuel properties was also investigated.

\section{Materials and methodology}

The palm biodiesel (98.8\% ester content) was procured from Senari Biofuels Sdn. Bhd, Sarawak. The anhydrous ethanol (99.5\% pure) was acquired from Sigma-Aldrich and the petro-diesel was procured from local petrol station at Kuching, Sarawak (Shell Malaysia). Two different fuel blends, namely, B0 (100\% diesel) and B20D70E10 (20\% biodiesel, 70\% diesel and 10\% ethanol) were prepared for immersion test. The carbon steel specimen of size $40 \mathrm{~mm}$ length, $25 \mathrm{~mm}$ width and $3 \mathrm{~mm}$ thickness was made from long flat plate by machining and grinding. The density of carbon steel $(0.2 \% \mathrm{C}, 0.4 \%$ $\mathrm{Mn}$ and $99.4 \% \mathrm{Fe}$ ) used in this study is $7.85 \mathrm{~g} / \mathrm{cm}^{3}$. To suspend the specimen into test fuel blends in the glass screw bottle, a hole of $3 \mathrm{~mm}$ diameter was drilled on the edge of the specimens. Before immersion, the specimens were polished using abrasive (SiC) grading papers until removing the scratches produced during cutting and grinding, and thereafter washed and degreased with acetone. Finally, the specimens were rinsed with deionized water, and then oven dried at $60{ }^{\circ} \mathrm{C}$ for $15 \mathrm{~min}$. Static immersion test was conducted for the carbon steel specimens in B0 and B20D70E10 at room temperature

Corresponding author: ${ }^{\mathrm{a}}$ sthangavelu $@$,swinburne.edu.my, ${ }^{\mathrm{b}}$ pchelladorai@, swinburne.edu.my, ${ }^{\mathrm{c}}$ farid $@$,fkm.utm.my 
(25 to $30{ }^{\circ} \mathrm{C}$ ) for $800 \mathrm{~h}$ and $60{ }^{\circ} \mathrm{C}$ for $400 \mathrm{~h}$. The weight of the specimens before and after the immersion test was measured using balance with accuracy of four decimal points. Immersion tests for triplicate specimens in each of the fuel blends were also conducted. The weight loss was calculated by deducting weight of the specimen after immersion from its weight before immersion. At the end of the immersion test, corrosion behaviors of carbon steel was studied by investigating corrosion rate (CR), morphology of corrosion products and chemical structure of carbon steel. The mean of weight loss measured from triplicate test specimens was converted into corrosion rate using Eq. (1) [4-9].

$$
\text { Corrosion rate }(\mathrm{CR})=\mathrm{W} \times 534 / \mathrm{D} \times \mathrm{T} \times \mathrm{A}
$$

Where corrosion rate 'mpy' stands for mils (0.001 inch) per year, $W$ is the mean weight loss (mg), $D$ is the density $\left(\mathrm{g} / \mathrm{cm}^{3}\right), T$ is the exposure time (h), and $A$ is the exposed surface area (square inch). The morphology of corrosion products was characterized by optical microscope (OM). Fourier transform infrared spectroscopy (FTIR) was used to investigate the chemical structure of carbon steel, before and after immersion. FTIR spectrum was recorded between 4000 and $400 \mathrm{~cm}^{-1}$ using Shimadzu spectrometer (Shimadzu, Japan) at $1 \mathrm{~cm}^{-}$ ${ }^{1}$ resolution and 10 scans per sample.

The degradation of fuel blends were studied by investigating the change of fuel properties, such as total acid number, density, viscosity, calorific value, flash point, color changes, water content, and oxidation products in the fuel. Total acid number (TAN) was determined using standard $0.1 \mathrm{M} \mathrm{KOH}$ solution (potassium hydroxide) by Potentiometric Titration method according to ASTM D664. A digital stabinger viscometer (SVM 3000, Anton Paar) was used to find the density at $15{ }^{\circ} \mathrm{C}$ (according to ASTM D7042) and kinematic viscosity (according to ASTM D445) at $40{ }^{\circ} \mathrm{C}$. FTIR spectroscopy was used to investigate the oxidation products (carbonyl groups) in the fuel according to ASTM D7414. Water content in the fuel was measured by standard test method according to ASTM E203, using volumetric Karl Fischer titration (Mettler Toledo-Karl Fischer Compact Titrator). Calorific value of the blends was determined by EKA 2000 Bomb Calorimeter according to ASTM D240. Flash point was measured by Pensky-Martens Closed cup apparatus according to ASTM D93. Color changes in the fuel blends were studied by visual inspection.

\section{Results and discussion}

\subsection{Corrosion rate}

The corrosion rate (CR) of carbon steel in B20D70E10 was 0.1817 and $0.2612 \mathrm{mpy}$ at room temperature and $60{ }^{\circ} \mathrm{C}$, respectively. These values are higher than $\mathrm{B} 0$ at both temperature conditions $(0.0523$ and $0.115 \mathrm{mpy}$ at room temperature and $60{ }^{\circ} \mathrm{C}$, respectively). As compared to previous studies $[4,8]$ reported for B100 (neat biodiesel), these CR in BDE fuel are slightly higher. According to Baena et al. [7], the fuel containing ethanol is more susceptible corrosion when exposed to ferrous material, which is due to occurrence of water and oxygen in the ethanol; moreover, no passivation exists in carbon steel, and corrosion products are not protective at low temperature atmosphere. The $\mathrm{CR}$ of carbon steel obtained in the present study at $60{ }^{\circ} \mathrm{C}$ is less than Cursaru et al. [6] and $\mathrm{Hu}$ et al. [5], whereas, Fazal et al. [8] obtained only $0.059 \mathrm{mpy}$ at $80{ }^{\circ} \mathrm{C}$ for $1200 \mathrm{~h}$ in palm biodiesel. This is due to the investigated carbon steel in that study contained $0.2 \% \mathrm{C}, 0.5 \% \mathrm{Mn}$, $0.5 \% \mathrm{Si}$ and $98.8 \% \mathrm{Fe}$ in composition, whereas the carbon steel used in the present study contains only $0.2 \%$ C, $0.4 \% \mathrm{Mn}$ and $99.4 \% \mathrm{Fe}$.

\subsection{Surface morphology}

Fig. 1 shows the morphology of corrosion products in the carbon steel surface exposed to fuel blends at room temperature $\left(25\right.$ to $30{ }^{\circ} \mathrm{C}$ ) and $60{ }^{\circ} \mathrm{C}$. Some surface damages was noticed due to corrosion on the surface of exposed to B20D70E10 fuel, compared to the surface of carbon steel in $\mathrm{B} 0$ at both temperature conditions.
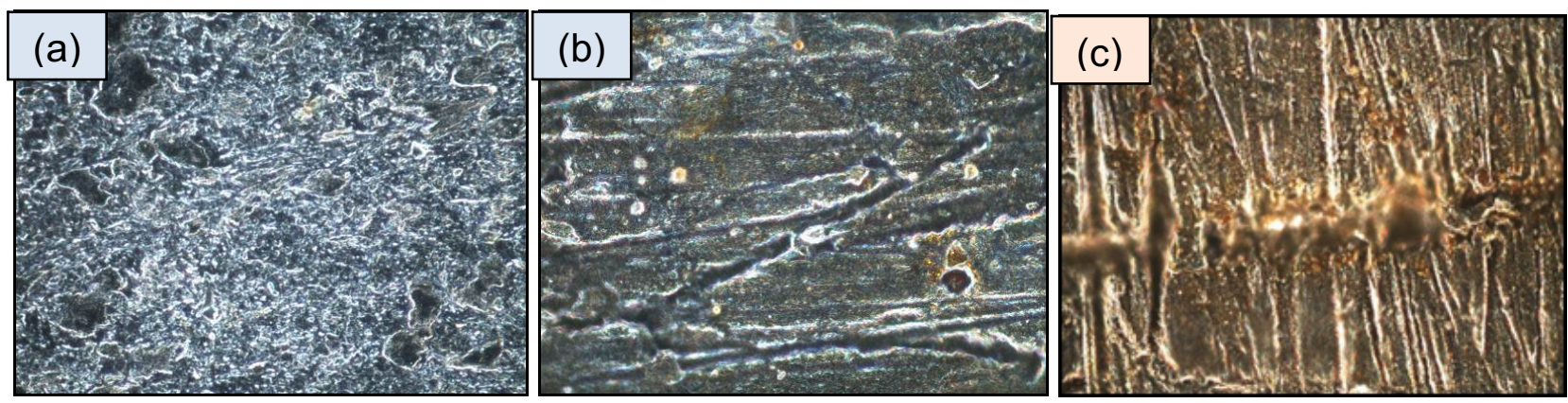

Figure 1. Surface morphology of carbon steel exposure to fuel (a) at room temperature in B0; (b) at room temperature in B20D70E10; (c) at $60^{\circ} \mathrm{C}$ in B20D70E10. 


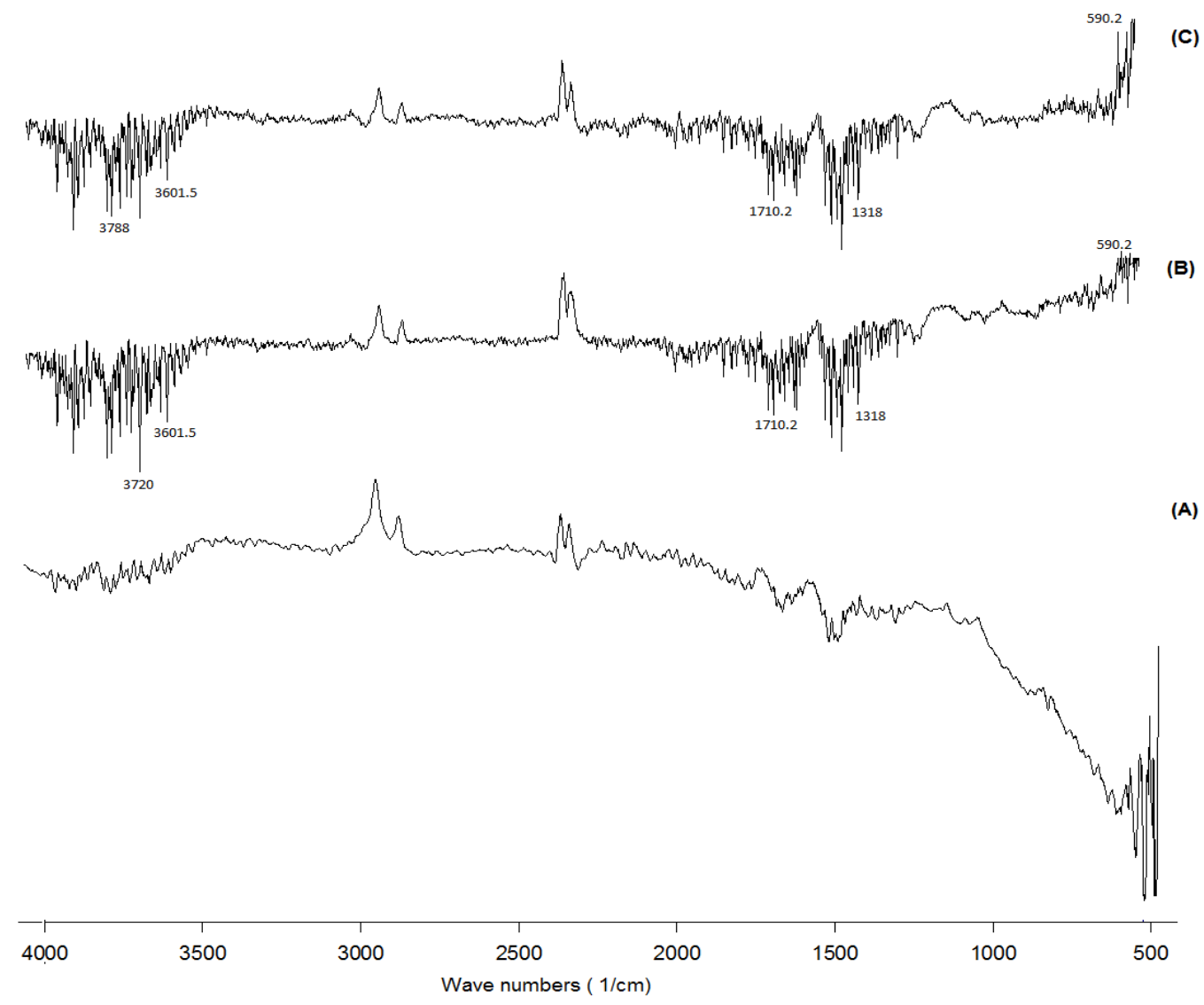

Figure 2. FTIR spectra of carbon steel upon exposure to B20D70E10 fuel blend (A) before exposure (B) after exposure at room temperature (C) after exposure at $60{ }^{\circ} \mathrm{C}$.

\subsection{Chemical structure}

Fig. 2 shows the change of chemical structure of carbon steel exposed to B20D70E10 fuel. The peak after immersion in the region $590 \mathrm{~cm}^{-1}$ indicates the presence of $\mathrm{Fe}_{2} \mathrm{O}_{3}$. The new peaks after immersion in the regions 1318 to $1710 \mathrm{~cm}^{-1}$ are indicating the formation of carboxylic acid and esters in the fuel, which produced the carboxylate corrosion product $\mathrm{Fe}_{2} \mathrm{O}_{2} \mathrm{CO}_{3}$. The free hydroxyl $(\mathrm{OH})$ groups in the regions 3601 to $3788 \mathrm{~cm}^{-1}$ indicate the presence of $\mathrm{Fe}(\mathrm{OH})_{3}$.

\subsection{Total acid number}

TAN is the measure of acid concentration in a nonaqueous solution. The TAN value of B20D70E10 exposed carbon steel was 1.15 and $1.59 \mathrm{mg} \mathrm{KOH} / \mathrm{g}$ at room temperature and $60{ }^{\circ} \mathrm{C}$, respectively. The permissible TAN limit for biodiesel as per ASTM standard D6751 (0.8 mg KOH/g) has been exceeded in BDE fuel upon exposure to carbon steel. TAN value does not directly measure the rate of oxidation, but it merely measures the by-products of oxidation in the fuel blends, hence the increase of TAN value in the fuel blends is due to increase of by-products of oxidation [9]. According to Fazal et al. [9], increase in TAN number indicates the presence of corrosive acids, which accelerates corrosion of metal. It can be inferred that the TAN values of BDE blend exposed to carbon steel in the present study is comparatively lower than the previous studies reported for neat biodiesel (B100).

Table 1. Change of B20D70E10 fuel properties at room temperature.

\begin{tabular}{|c|c|c|}
\hline Fuel properties & As-Received & $\begin{array}{c}\text { Exposed to } \\
\text { carbon steel }\end{array}$ \\
\hline $\begin{array}{c}\text { Total acid number }(\mathrm{mg} \\
\mathrm{KOH} / \mathrm{g})\end{array}$ & 0.25 & 1.15 \\
\hline Density $(\mathrm{kg} / \mathrm{m} 3)$ & 846.8 & 855.3 \\
\hline Viscosity $(\mathrm{mm} 2 / \mathrm{s})$ & 2.4796 & 2.757 \\
\hline Calorific value $(\mathrm{MJ} / \mathrm{kg})$ & 40.524 & 43.452 \\
\hline Flash point $\left({ }^{\circ} \mathrm{C}\right)$ & 16 & 17 \\
\hline $\begin{array}{c}\text { Oxidation } \text { products } \\
(\text { Abs. } / 0.1 \mathrm{~mm})\end{array}$ & 1.67 & 3.03 \\
\hline Water content $(\%)$ & 0 & 0.17 \\
\hline
\end{tabular}

\subsection{Density and viscosity}

It can be noticed that the B20D70E10 fuel blend exposed to carbon steel have increased in density (as in Table 1), which is due to conversion of metal elements into the fuel blends at oxygen atmosphere [8]. However, it is noticeable that exposed BDE fuel blend show a density value within the limit for biodiesel ( 0.86 to 0.9 
$\mathrm{g} / \mathrm{cc}$ ) as stated by specific standard EN 14214. Moreover, there was slight variation in the viscosity of BDE fuel blend exposed to carbon steel (as in Table 1). However, these values are within the permissible limit for biodiesel ( 2 to $6 \mathrm{~mm}^{2} / \mathrm{s}$ ) as specified by ASTM D6751.

\subsection{Calorific value and flash point}

The initial calorific value $(\mathrm{CV})$ of B20D70E10 was $40.524 \mathrm{MJ} / \mathrm{kg}$, which is increased to $43.452 \mathrm{MJ} / \mathrm{kg}$ after exposure to carbon steel. Conversely, there is no big change in the $\mathrm{CV}$ of diesel (B0) before and after exposure carbon steel. The main reason for increased in $\mathrm{CV}$ for BDE fuel is due to change in the composition of BDE fuel (reduced oxygen content) when exposed to metal. Fazal et al. [4] reported that the CV of biodiesel increases in the presence of metal elements, and changes in calorific values may depend on the types of molecules formed after hydrolysis of esters. There was a slight change in the flash point (from 16 to $17^{\circ} \mathrm{C}$ ) of B20D70E10 exposed to carbon steel (as in Table 1).

\subsection{Oxidation products}

The oxidation products level in the B20D70E10 increased upon exposure to carbon steel (as in Table 1). The main ethanol oxidation products are ethanol acetaldehyde, ketone, carbonic acid and acetic acid. The oxidation of biodiesel can produce different types of acids, such as octanoic acid, myristic acid, palmitic acid etc. In addition to these acids, different types of other short chain esters, aldehydes, and ketones are found to be produced. Apart from increasing the corrosiveness of biodiesel, these oxidation products may also degrade the fuel properties by reacting with esters, and thereby increasing total acid number [8].

\subsection{Water content}

Water content is the main component to make the fuel more aggressive. The received B20D70E10 blend had no water content $(0 \%)$. However, the water content increased after immersion (as in Table 1), which indicates, BDE fuel blends absorbed more water compared to B0. The maximum permissible limit of water content is 0.05 (vol. \%) for both diesel and biodiesel according to ASTM standard D975 and D6751, respectively. In this present study, water content in BDE blends exposed to carbon steel exceeded the maximum limit. However, the maximum acceptable moisture content for fuel grade ethanol as stated by ASTM E203 is 1\%. In summary, the percentage of water content obtained in the present study is lower than previous studies reported for B100 [5-9]. As in Fig. 3, carbon steel exposed BDE fuel blend changed to dark reddish yellow color at $60{ }^{\circ} \mathrm{C}$, which is due to the formation of iron oxides $\left(\mathrm{Fe}_{2} \mathrm{O}_{3}\right)$

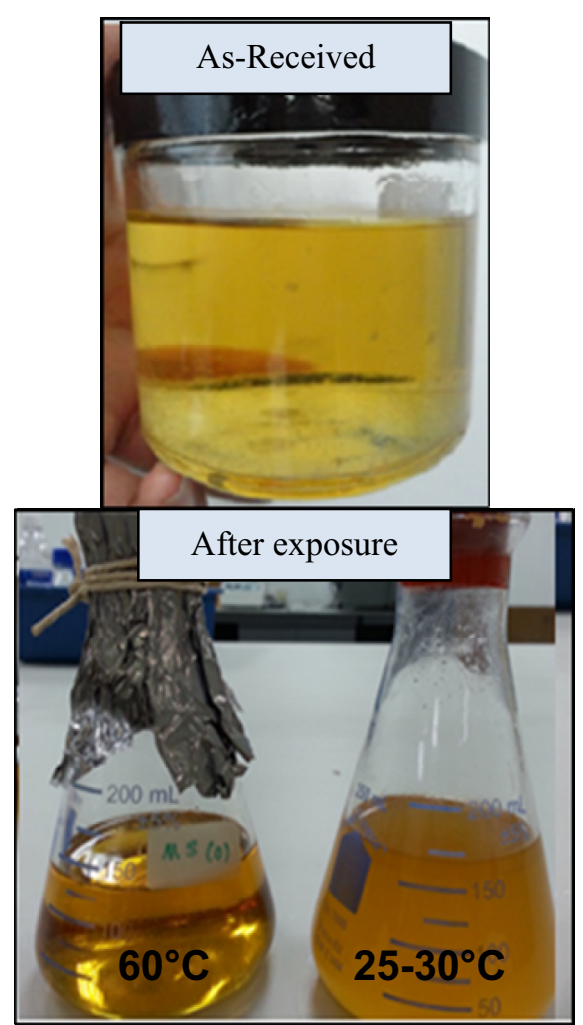

Figure 3. Colour changes of B20D70E10 fuel blend upon exposure to carbon steel.

\section{Conclusion}

Corrosion behavior of carbon steel in biodieseldiesel-ethanol blend fuel (B20D70E10) was studied. Corrosion rate of carbon steel in B20D70E10 fuel blend was slightly higher than petro-diesel (B0). Degradation of fuel properties in B20D70E10, such as TAN, density, viscosity, $\mathrm{CV}$, flash point, oxidation products, and water content are lower than neat biodiesel (B100) and slightly higher than petro-diesel (B0).

\section{References}

1. Demirbas, Appl. Energ. 88, 17-28 (2011).

2. P. Kwanchareon, A. Luengnaruemitchai, S. Jai-In, Fuel 86, 1053-61 (2007).

3. S. A. Shahir, H. H. Masjuki, M. A. Kalam, A. Imran, I. M. Rizwanul Fattah, A. Sanjid, Renew. Sust. Energ. Rev. 32, 379-395 (2014).

4. M. A. Fazal, M. R. Jakeria, A. S. M. A. Haseeb, Ind. Crop. Prod. 58, 8-14 (2014).

5. E. Hu, Y. Xu, X. Hu, L. Pan, S. Jiang, Renew. Energ. 37, 371-378 (2012).

6. D. L. Cursaru, G. Branoiu, I. Ramada, F. Miculescu, Ind. Crop. Prod. 54, 149-158 (2014).

7. L.M. Baena, M. Gómez, J. A. Calderón. Fuel 95, 320-328 (2012).

8. M.A. Fazal, A. S. M. A. Haseeb, H. H. Masjuki, Energy 36, 3328-3334 (2011).

9. M.A. Fazal, A. S. M. A. Haseeb, H. H. Masjuki, Energy 40, 76-83 (2012). 